\title{
A Critical Period in Purkinje Cell Development Is Mediated by Local Estradiol Synthesis, Disrupted by Inflammation, and Has Enduring Consequences Only for Males
}

\author{
- Jessica F. Hoffman, ${ }^{*}$ CChristopher L. Wright, ${ }^{*}$ and $\odot$ Margaret M. McCarthy \\ Program in Neuroscience and Department of Pharmacology, University of Maryland School of Medicine, Baltimore, Maryland 21201
}

Identifying and understanding critical periods in brain development is essential to decoding the long-term impact of widespread, poorly defined, and frequently occurring insults such as inflammation. Using the laboratory rat Rattus norvegicus, we have discovered a narrowly constrained critical period in Purkinje neuron development subject to dysregulation by inflammation. The onset and offset of heightened vulnerability are attributed to a tightly orchestrated gene expression profile present only during the second postnatal week and not the first or third weeks. Genes expressed during this time code for enzymes and receptors which are critical not only for prostaglandin production and activity but also for estradiol production via the aromatase enzyme and estradiol action via the $\alpha$ isoform of the estrogen receptor. The two synthetic pathways are connected by prostaglandin E2 (PGE2) activation of the aromatase enzyme, as we reported previously (Dean et al., 2012b) and confirm here. Dysregulation of the PGE2- estradiol pathway during the second week by treatment with PGE2 or lipopolysaccharides produces enduring consequences as a result of reduced growth of Purkinje dendritic trees and impaired juvenile social play behavior, but only in males. The deleterious consequences of inflammation locally in the cerebellum are prevented by peripheral treatment with the cyclooxygenase inhibitor nimesulide or the aromatase inhibitor formestane. These findings highlight a novel regulatory pathway that creates a critical period in brain development vulnerable to dysregulation by inflammation.

Key words: cerebellum; estradiol; inflammation; prostaglandin; Purkinje cell; social play

Significance Statement

The cerebellum is increasingly appreciated for its role in social, emotional, and cognitive behaviors. It is consistently and severely affected in neuropsychiatric disorders originating during development, such as autism spectrum disorder and schizophrenia. We have identified a critical period in rat development during the second week of life that is dysregulated by inflammatory insults. An intrinsic program of gene expression determines the critical period. The enduring consequences of inflammation during the second postnatal week are stunted dendrites of the cerebellum's principal neurons, Purkinje cells, and impairments in later social behavior. These changes are not evident if inflammation occurs during the first or third week, highlighting the importance of fine-grained analyses of developmental processes and the factors that influence them.

\section{Introduction}

The cerebellum is one of the first brain structures to differentiate, yet one of the last to fully mature, making it particularly susceptible to developmental perturbations (Wang and Zoghbi, 2001).

\footnotetext{
Received April 14, 2016; revised July 22, 2016; accepted July 24, 2016

Author contributions: J.F.H., C.L.W., and M.M.M. designed research; J.F.H. and C.L.W. performed research; J.F.H., C.L.W., and M.M.M. contributed unpublished reagents/analytic tools; J.F.H., C.L.W., and M.M.M. analyzed data; J.F.H., C.L.W., and M.M.M. wrote the paper.

This work was supported by the National Institute of Mental Health-National Institutes of Health (Grant R01 MH091424 to M.M.M. and National Research Service Award Grant MH096532-01A1 to J.F.H.).

*J.F.H. and C.L.W. contributed equally to this work.

Correspondence should be addressed to Dr. Christopher Wright, Program in Neuroscience and Department of Pharmacology, University of Maryland, 685 W. Baltimore St., Brb 5014, Baltimore, MD 21201. E-mail: cwrig003@umaryland.edu.

DOI:10.1523/JNEUROSCI.1262-16.2016

Copyright $\odot 2016$ the authors $\quad 0270-6474 / 16 / 3610039-11 \$ 15.00 / 0$
}

Increasing awareness that the cerebellum is reciprocally connected with the prefrontal cortex (Strick et al., 2009; Stoodley and Schmahmann, 2010; Buckner et al., 2011) and centrally involved in complex social, emotional, and cognitive behaviors compels an increased understanding of how this region develops (Schmahmann and Sherman, 1998). Purkinje neurons are the principal cells and sole output of the cerebellar cortex and undergo considerable growth postnatally. In the rodent, the second postnatal week is the most dynamic with significant cytoarchitectural changes in the growth and innervation of the Purkinje cell dendritic tree. Between the first and second weeks, Purkinje cells transition from a stellate morphology into their quintessential dendritic structure that is highly-branched, electrotonically compact but has just not yet reached maximal length (Altman, 1972; Roth and Häusser, 2001). Early in development, Purkinje cells are 
innervated by multiple climbing fibers, but during the second week, this is reduced to only one by selective pruning, leading to the determination by others that this is a critical period (Kakizawa et al., 2000).

Estradiol is a steroid hormone aromatized from androgen precursors (Naftolin, 1994) and is predominantly derived in the gonads. However, the brain expresses high levels of the aromatase enzyme, particularly in humans (Sasano et al., 1998; Biegon et al., 2010). Both isoforms of the estrogen receptor (ER) are expressed by cerebellar neurons, with ER $\alpha$ (Esr1) notable for much higher expression early in development and restricted to Purkinje cells. The aromatase gene (Сyp19a) is also expressed by developing Purkinje cells, suggesting cell-autonomous developmental regulation by estradiol (Hedges et al., 2012).

While exploring cerebellar development in the postnatal rat, we determined that prostaglandin E2 (PGE2) stimulates aromatase activity, leading to increased estradiol that then regulates normal Purkinje cell development (Dean et al., 2012b). PGE2 is produced from arachidonic acid (AA) by two enzymes acting sequentially, the cyclooxygenases (COX-1 and COX-2), followed by prostaglandin $\mathrm{E}$ synthase (PGES). In the brain, most AA is synthesized from the endocannabinoid 2-arachidonoylglycerol by monoacylglycerol (MAG) lipase (Mll) (Nomura et al., 2011). PGE2 is an autocrine or paracrine molecule that autonomously regulates the maintenance of a multitude of cellular processes throughout the body. In the brain, PGE2 regulates synaptogenesis in the preoptic area (POA) (Amateau and McCarthy, 2002; Amateau and McCarthy, 2004), stimulates glutamate release from astrocytes (Bezzi et al., 1998), triggers secretion of GnRH (Rage et al., 1997), modulates sensorimotor gating and LTD (Savonenko et al., 2009), integrates dopaminergic responses to social defeat stress (Tanaka et al., 2012), and modulates vasodilation in response to low oxygen content (Attwell et al., 2010). In addition to these regulatory roles, PGE2 also serves as sentinel that integrates immunomodulatory cues into the cellendogenous processes. Elevation of brain PGE2 initiates fever, central hyperalgesia, and sickness behavior (Blatteis et al., 2005; Chell et al., 2006).

In the cerebellum, if the PGE2-E2 response pathway is thrown out of balance by exogenous PGE2 or inhibition of the aromatase or COX enzymes during the second postnatal week, the Purkinje dendritic tree is either stunted or overgrown, respectively, and animals later exhibit abnormal social interactions, increased object exploration, and hypersensitivity to touch (Dean et al., 2012a; Dean et al., 2012b). Given PGE2's dual role as an endogenous factor and an inflammatory mediator, we investigated the following: (1) whether the endogenous PGE2-E2 signaling pathway can be triggered by mimetics of infection peripherally; (2) whether this cell-autonomous pathway is restricted to the second postnatal week; and (3) whether there is a developmentally regulated process of gene expression underpinning not only the week 2 sensitivity, but also the coupling of the autonomous process of cerebellar development with peripheral inflammatory responses.

\section{Materials and Methods}

\section{Animals}

All animal use was conducted in accordance with the Institutional Animal Care and Use Committee guidelines of the University of Maryland School of Medicine and accepted standards of humane animal care. Sprague Dawley rats Rattus norvegicus were maintained on a 12:12 reverse light cycle with ad libitum food and water. Female dams were either mated in our animal facility, or ordered (Charles River Laboratories) by pregnancy date at least $3 \mathrm{~d}$ before giving birth. Pregnant females were isolated and allowed to deliver normally. On day of birth (postnatal day
0, PN0), litters were culled to no more than 12 pups, divided evenly across sexes and mix-fostered to avoid confounding variables of maternal rearing. Pups remained with their dams until they were humanely killed or reached PN23, at which point they were weaned and housed two to three animals per same-sex cage.

\section{Injection methods and drug doses}

Treatment paradigms fell within one of three time frames: (1) week 1 , between PN1 and PN7; (2) week 2, between PN8 and PN14; or (3) week 3 , between PN15 and PN21. The exact timing and frequency of each injection paradigm and euthanasia varied by experiment. At their first treatment, animals received a single injection of India ink to a paw pad for group identification.

Lipopolysaccharide (LPS) from Eschericia coli Strain K-235 (catalog \#L2143; Sigma-Aldrich) was given intraperitoneally at a $200 \mu \mathrm{g} / \mathrm{kg}$ dose in $0.04-0.1 \mathrm{ml}$ of pyrogen-free saline either once or twice, but if twice, each injection was on a separate day.

Nimesulide $(5 \mathrm{mg} / \mathrm{kg})$ is a COX-2 inhibitor and was given subcutaneously daily from PN7-10 in $0.08-0.1 \mathrm{ml}$ of sesame oil.

PGE2 (2.5 $\mu \mathrm{g}$ in $1 \mu \mathrm{l}$ of pyrogen-free saline) was given to pups via an intracranial injection through the foramen magnum (FM). If pups were younger than PN7, they were cryoanesthetized. Pups older than PN7 were anesthetized initially under $0.4 \%$ isoflurane for $2-3 \mathrm{~min}$ and then, if necessary, maintained at $0.2 \%$ isoflurane during injection. All pups were placed on a stereotaxic apparatus and the long axis of the head was along the length of the $25 \mathrm{Ga}$ needle of the $1.0 \mu \mathrm{l}$ Hamilton syringe. The needle was lowered to a 3-4 $\mathrm{mm}$ total depth until piercing the meninges at the FM. A volume of $1.0 \mu \mathrm{l}$ containing drug or vehicle was injected over $30 \mathrm{~s}$ and the needle left in place for an additional $30 \mathrm{~s}$. After injections, pups were warmed under a heat lamp and, when fully active, returned to the dam, generally within $1 \mathrm{~h}$.

Formestane is an aromatase inhibitor and $1 \mu \mathrm{g}$ was suspended in $1 \mu \mathrm{l}$ of $0.9 \%$ pyrogen-free saline containing $0.25 \mu \mathrm{g}$ of rat serum albumin and injected into the FM on PN10.

$\mathrm{Ht} 31$ is a protein kinase A (PKA) signaling disruptor, because it is a stearated peptide identical to the amphipathic helix on A-kinase anchoring proteins (AKAPs) to which type II PKA binds. After the stearated moiety promotes cellular uptake, $\mathrm{Ht} 31$ binds to PKA, removing it from AKAPs and macromolecular signaling complexes and reducing phosphorylation of PKA substrates. Nine nanomoles of Ht31 or control protein $(\mathrm{CP})$, an analog containing a proline substitution, were given via an FM injection described above.

\section{Dissection and collection of cerebellar tissue}

Animals older than PN7 were humanely killed by lethal overdose with a pentobarbital sodium solution (Fatal Plus; Vortech Pharmaceuticals). For Golgi-Cox impregnation, the whole brain was placed immediately into Golgi-Cox solution, described below. For assays other than GolgiCox impregnation, the posterior vermis was separated from the rest of the cerebellum and immediately flash frozen and stored at $-80^{\circ} \mathrm{C}$ until homogenization. The POA was dissected as described previously (Amateau and McCarthy, 2004).

\section{PGE2 and estradiol assays}

Frozen tissue was homogenized in ice-cold RIPA buffer and PGE2 quantified as described previously (Dean et al., 2012a). For estradiol quantification, samples were sent to the Center for Research in Reproduction (University of Virginia, Charlottesville) and analyzed by radioactive immunoassay as described previously (Konkle and McCarthy, 2011).

\section{Aromatase activity assay}

Aromatase activity was quantified by measuring tritiated water production using a previously validated method with modifications as described previously (Dean et al., 2012b). The posterior vermes and hemispheres were combined from two rats to represent one sample.

\section{Purkinje cell reconstruction}

Whole brains were placed in $30 \mathrm{ml}$ of Golgi-Cox solution and embedded according to a protocol described previously (Dean et al., 2012b). 
Table 1. Rat transcript CDNA PCR primers and conditions

\begin{tabular}{|c|c|c|c|c|c|}
\hline Gene & $\begin{array}{l}\text { PubMed } \\
\text { accession no }\end{array}$ & $\begin{array}{l}\text { Forward primer and start position for first variant } \\
\text { Reverse primer and start position for first variant }\end{array}$ & $\begin{array}{l}\text { Amplicon } \\
\text { length }\end{array}$ & $\begin{array}{l}\text { Annealing } \\
\text { temperature }\left({ }^{\circ} \mathrm{C}\right)\end{array}$ & $\begin{array}{l}\text { Melting } \\
\text { temperature }\left({ }^{\circ} \mathrm{C}\right)\end{array}$ \\
\hline PTGS1 (COX1) & NM_017043.3 & $\begin{array}{l}\text { F 5'-AAAGAACCCAATGTCCAGCAAG; } 2555 \text { bp } \\
\text { R 5'-GGCTCCCAACCAAAATCGTAG; } 2706 \text { bp }\end{array}$ & 152 bp & 60.8 & 80.9 \\
\hline PTGS2 (COX2) & NM_017232.3 & $\begin{array}{l}\text { F 5'-TTCCAGTATCAGAACCGCATTG; } 1069 \text { bp } \\
\text { R 5'-CAGCAAGTCCGTGTTCAAGGA; } 1219\end{array}$ & 151 bp & 60.8 & 80.3 \\
\hline PGES1 (Microsomal PGE-synthase-1) & NM_021583.2 & $\begin{array}{l}\text { F 5'-GCAACGACATGGAGACGATCT; } 263 \text { bp } \\
\text { R 5'-CATGGAGAAACAGGCGAACTG; } 465 \text { bp }\end{array}$ & 203 bp & 58 & 84.2 \\
\hline Mgll (MAG Lipase) & NM_138502.2 & $\begin{array}{l}\text { F 5'-CATGGAGCTGGGGAACACTG; } 262 \text { bp } \\
\text { R 5'-GGAGATGGCACCGCCCATGGAG; } 501 \text { bp }\end{array}$ & 239 bp & 58 & 81 \\
\hline PTGER2 (EP2) & NM_031088 & $\begin{array}{l}\text { F 5'-CTTGCTCTTCTGTTCTCTGCCG; } 537 \text { bp } \\
\text { R 5'-GCTTCTTTTGCTCCGAAGCTG; } 741 \text { bp }\end{array}$ & 205 bp & 60.8 & 85 \\
\hline PTGER3 (EP3) & NM_012704 & $\begin{array}{l}\text { F 5'-TTGTGTCGCGCAGCTATAGAC; } 231 \text { bp } \\
\text { R 5'-TCCGAACACTGTCATGGTCAG; } 429 \text { bp }\end{array}$ & 209 bp & 60 & 87 \\
\hline PTGER4 (EP4) & NM_032076 & $\begin{array}{l}\text { F 5'-TGCTCAGAGAGTCGGAGGACAAT; } 1276 \text { bp } \\
\text { R 5'-GAAATTCGCAAAGTTCTCAGCG; } 1490 \text { bp }\end{array}$ & 215 bp & 60 & 84.5 \\
\hline CYP19A1 (Aromatase) & NM_017085.2 & $\begin{array}{l}\text { F 5'-AACGTGAATCAGTGTATATTGGAAATG; } 1495 \text { bp } \\
\text { R 5'-CGTACAGAGTGACGGACATGG; } 1561 \text { bp }\end{array}$ & $67 \mathrm{bp}$ & 56 & 77.5 \\
\hline ESR1 $(E R \alpha)$ & NM_012689.1 & $\begin{array}{l}\text { F 5' -GAAAGGCGGGATACGAAAAGA; } 977 \text { bp } \\
\text { R 5'- TCTGACGCTTGTGCTTCAACA; } 1035 \text { bp }\end{array}$ & $59 \mathrm{bp}$ & 60 & 76.8 \\
\hline ESR2 (ER $\beta)$ & NM_012754.1 & $\begin{array}{l}\text { F 5'-TCTGTCCAGCCACGAATCAG; } 1035 \text { bp } \\
\text { R 5'-GGCCTGGCAGCTTTTACG; } 1093 \text { bp }\end{array}$ & $59 \mathrm{bp}$ & 60 & 79.1 \\
\hline GAPDH & NM_017008.4 & $\begin{array}{l}\text { F 5'-TGGTGAAGGTCGGTGTGAACGG; } 77 \text { bp } \\
\text { R 5'-TCACAAGAGAAGGCAGCCCTGGT; } 146 \text { bp }\end{array}$ & $70 \mathrm{bp}$ & $56-60.8$ & 80.9 \\
\hline
\end{tabular}

Reconstruction of cellular morphology was performed under a Nikon $60 \times$ objective using the Neurolucida system (Nikon Eclipse E600 microscope; MicrobrightField CX900 CCD camera). Three to five posterior vermal Purkinje neurons per animal identified by lobule, layer, and morphology were selected randomly by a researcher blinded to sex and treatment. The soma and the entire dendritic tree was reconstructed, which allowed for calculation of the sum total of dendrite length traced, the number of nodes in the dendrites, the average length of each segment, the number of overall segments, and the size of the soma. Individual animals were treated as the subjects for statistical examination.

\section{Behavior}

All behavioral tests were conducted during the dark phase under red light illumination. All of the behavioral tests were done according to protocols described previously (Dean et al., 2012a). Negative geotaxis was assessed in PN13 rat pups and wire hang in PN19 pups, during which their forepaws grasped a 2-mm-diameter wire for a recorded duration not $>2$ min. Activity in an open field was assessed at PN25 and PN60. Engagement in juvenile social play was assessed every other day from PN28 to PN38 in play groups of five to six rats of mixed sex and treatment and did not include home cage mates.

\section{$R N A$ extraction and $q P C R$}

RNA extraction used the protocol for fatty tissues from the RNeasy Handbook for Mini Kit (catalog \#74106; Qiagen). Single-stranded complementary DNA (cDNA) was generated from extracted RNA using the ABI High-Capacity cDNA Reverse Transcription Kit (cata$\log$ \#4368814). Unless otherwise mentioned, primers were designed using Primer Express from Applied Biosystems (Table 1). qPCR was conducted on standards and samples run in triplicate using the SYBR green relative quantification method with a standard curve on a 384 well plate, using an Applied Biosystems ViiA7 with 384-well block. The primers used for each gene were common to all variants for that gene and thus potentially amplified all known and predicted variants together. GAPDH was used as mRNA loading control to normalize all genes. GAPDH was run at the same melting temperature as each target gene while confirming no loss of efficiency over that range.

\section{Experimental paradigms}

Experiment 1A: Effect of LPS treatment on cerebellar PGE2 content. Male and female pups were injected peripherally with LPS on either 1 or $2 \mathrm{~d}$ during one of the first three postnatal weeks. Numbers per group, age of pups at injection and timing of tissue collection are presented below (Fig. 1A).

Experiments $1 B$ and $1 C$ : Effect of intracerebellar infusion of PGE2 or peripheral LPS on E2 and Purkinje neuron morphology. Male and female pups were infused with PGE2 directly into the cerebellum or injected peripherally with LPS. Numbers per group, age of pups at injection, and timing of tissue collection are presented below (Fig. 1B).

Experiment 2A: Effects of intracerebellar infusion of PGE2 on motor and juvenile social play behaviors. Male and female pups were treated in the same manner as in Experiment $1 \mathrm{~B}$ and then tested for various behaviors. Numbers per group, age of pups at injection and timing of behavioral tests are presented below (Fig. 1C).

Experiment 2B: Effects of peripheral LPS on motor and juvenile social play behaviors. Male and female pups were injected peripherally with LPS and then assessed for various behaviors. Numbers per group, age of pups at injection and timing of behavioral tests are presented below (Fig. 1D).

Experiment 3A: Effects of LPS treatment on mRNA levels of key genes. Male and female pups were injected peripherally with LPS and tissue was taken $1 \mathrm{~h}$ later. Numbers per group and age of pups at injection are presented below (Fig. 1E).

Experiment 3B: Expression of PGE2 and E2 synthesizing and signaling genes during the first three postnatal weeks. Untreated animals were humanely killed on PN3, PN5, PN7, PN10, PN12, PN14, PN17, PN19, or PN21 ( $n=7$ or 8 for each age) and the posterior vermes flash frozen for use for mRNA extraction and qPCR quantification of the genes coding for Mgll; COX-1 and COX-2 (Ptgs1 and Ptgs2, respectively); microsomal PGES-1 (Pges1); EP2, EP3, and EP4 (Ptger2, Ptger3, and Ptger4, respectively); aromatase (Cyp19A1); and ER- $\alpha$ and ER- $\beta$ (Esr1 and Esr2, respectively).

Experiments $4 A$ and $4 B$ : Effect of LPS treatment on cerebellar aromatase activity and estradiol levels with and without and cotreatment with the COX-2 inhibitor nimesulide. Male and female pups were injected peripherally with nimesulide and/or LPS and tissue was taken. Numbers per group, age of pups at injection, and timing of tissue collection are presented below (Fig. $1 F$ ).

Experiment 4C: Effect of PKA signaling disruptor Ht31on PGE2-induced aromatase activity. Male and female pups were injected into the FM with either $\mathrm{Ht} 31$ or CP and then either PGE2 or saline and tissue was taken $16 \mathrm{~h}$ after the last injection. Two animals pooled per $n$; $n$ per group, and age of pups at injection are presented below (Fig. $1 G$ ).

Experiment 4D: Effect of peripheral LPS and peripheral formestane on Purkinje dendritic morphology. Male and female pups were injected peripherally with either forestane or vehicle and either LPS or vehicle and 


\begin{tabular}{|c|c|c|c|c|c|}
\hline \multicolumn{6}{|c|}{ A) Experiment 1A } \\
\hline & $\begin{array}{l}\text { Treatment } \\
\text { group }\end{array}$ & $\begin{array}{c}\text { Age at } \\
\text { injections }\end{array}$ & $\begin{array}{l}M \\
(n)\end{array}$ & $\begin{array}{l}F \\
(n)\end{array}$ & $\begin{array}{c}\text { Age at } \\
\text { tissue } \\
\text { collection }\end{array}$ \\
\hline \multirow{2}{*}{$\begin{array}{l}\text { Week } 1 \\
\text { (PN1-7) }\end{array}$} & Veh (saline) & PN4 & 5 & 6 & \multirow{8}{*}{$\begin{array}{l}6 \mathrm{~h} \text { after } \\
\text { final } \\
\text { injection }\end{array}$} \\
\hline & LPS (1d) & PN4 & 6 & 6 & \\
\hline \multirow{3}{*}{$\begin{array}{c}\text { Week 2 } \\
\text { (PN8-14) }\end{array}$} & Veh (saline) & PN9 + PN10 & 16 & 15 & \\
\hline & LPS (1d) & PN9 + PN10 & 21 & 15 & \\
\hline & LPS (2d) & PN9 + PN10 & 11 & 7 & \\
\hline \multirow{3}{*}{$\begin{array}{c}\text { Week 3 } \\
\text { (PN15-21) }\end{array}$} & Veh (saline) & PN16 + PN17 & 19 & 15 & \\
\hline & LPS (1d) & PN16 + PN17 & 21 & 19 & \\
\hline & LPS (2d) & PN16 + PN17 & 7 & 10 & \\
\hline
\end{tabular}

\begin{tabular}{|c|c|c|c|c|c|}
\hline \multicolumn{6}{|c|}{ C) Experiment 2A } \\
\hline & $\begin{array}{l}\text { Treatment } \\
\text { group }\end{array}$ & $\begin{array}{c}\text { Age at } \\
\text { injections }\end{array}$ & $\begin{array}{c}M \\
(n)\end{array}$ & $\begin{array}{l}\mathbf{F} \\
(n)\end{array}$ & $\begin{array}{c}\text { Age at behavior } \\
\text { analysis } \\
\text { (same for all } \\
\text { treatments) }\end{array}$ \\
\hline \multirow{2}{*}{$\begin{array}{l}\text { Week 2 } \\
\text { (PN8-14) }\end{array}$} & $\begin{array}{l}\text { Vehicle } \\
\text { (saline) }\end{array}$ & PN10 + PN12 & 6 & 8 & \multirow{4}{*}{$\begin{array}{l}\text { PN13: Negative } \\
\text { geotaxis } \\
\text { PN19: Wire hang } \\
\text { PN25: Open field } \\
\text { PN28-28: Social } \\
\text { play } \\
\text { PN60: Open field }\end{array}$} \\
\hline & PGE2 & PN10 + PN12 & 8 & 7 & \\
\hline \multirow{2}{*}{$\begin{array}{l}\text { Week } 3 \\
\text { (PN15-21) }\end{array}$} & $\begin{array}{l}\text { Vehicle } \\
\text { (saline) }\end{array}$ & PN17 + PN19 & 7 & 7 & \\
\hline & PGE2 & PN17 + PN19 & 7 & 7 & \\
\hline
\end{tabular}

\begin{tabular}{|c|c|c|c|c|c|}
\hline \multicolumn{6}{|c|}{ E) Experiment 3A } \\
\hline & $\begin{array}{l}\text { Treatment } \\
\text { group }\end{array}$ & $\begin{array}{c}\text { Age at } \\
\text { injections }\end{array}$ & $\begin{array}{c}M \\
(n)\end{array}$ & $\begin{array}{l}F \\
(n)\end{array}$ & $\begin{array}{c}\text { Age at } \\
\text { tissue } \\
\text { collection }\end{array}$ \\
\hline \multirow{2}{*}{$\begin{array}{l}\text { Week } 1 \\
\text { (PN1-7) }\end{array}$} & Veh (saline) & PN4 & 4 & 4 & \multirow{6}{*}{$\begin{array}{l}1 \mathrm{hr} \text { after } \\
\text { injection }\end{array}$} \\
\hline & LPS & PN4 & 4 & 3 & \\
\hline \multirow{2}{*}{$\begin{array}{c}\text { Week 2 } \\
\text { (PN8-14) }\end{array}$} & Veh (saline) & PN10 & 3 & 6 & \\
\hline & LPS & PN10 & 5 & 6 & \\
\hline \multirow{2}{*}{$\begin{array}{c}\text { Week 3 } \\
\text { (PN15-21) }\end{array}$} & Veh (saline) & PN17 & 4 & 6 & \\
\hline & LPS & PN17 & 4 & 6 & \\
\hline
\end{tabular}

\begin{tabular}{|c|c|c|c|c|c|}
\hline \multicolumn{6}{|c|}{ G) Experiment 4C } \\
\hline & $\begin{array}{l}\text { Treatment } \\
\text { group }\end{array}$ & $\begin{array}{c}\text { Age at } \\
\text { injections }\end{array}$ & $\begin{array}{l}M \\
(n)\end{array}$ & $\begin{array}{l}F \\
(n)\end{array}$ & $\begin{array}{c}\text { Age at } \\
\text { tissue } \\
\text { collection }\end{array}$ \\
\hline \multirow{4}{*}{$\begin{array}{c}\text { Week } 2 \\
\text { (PN8-14) }\end{array}$} & $\begin{array}{l}\text { Vehicle } \\
\text { (saline + CP) }\end{array}$ & PN10 + PN10 & 3 & 4 & \multirow{4}{*}{$\begin{array}{c}16 \mathrm{~h} \text { after } \\
\text { final } \\
\text { injection }\end{array}$} \\
\hline & PGE2 + CP & PN10 + PN10 & 3 & 3 & \\
\hline & PGE2 + Ht31 & PN10 + PN10 & 3 & 4 & \\
\hline & Saline + Ht31 & PN10 + PN10 & 3 & 4 & \\
\hline
\end{tabular}

\begin{tabular}{|c|c|c|c|c|c|}
\hline \multicolumn{6}{|c|}{ I) Experiment 4E } \\
\hline & $\begin{array}{l}\text { Treatment } \\
\text { group }\end{array}$ & $\begin{array}{c}\text { Age at } \\
\text { injections }\end{array}$ & $\begin{array}{c}\mathrm{M} \\
(n)\end{array}$ & $\begin{array}{l}\mathrm{F} \\
(n)\end{array}$ & $\begin{array}{l}\text { Age at behavior } \\
\text { analysis } \\
\text { (same for all } \\
\text { treatments) }\end{array}$ \\
\hline \multirow{4}{*}{$\begin{array}{l}\text { Week } 2 \\
\text { (PN8- } \\
14)\end{array}$} & $\begin{array}{l}\text { Vehicle } \\
\text { (saline both) }\end{array}$ & $\begin{array}{l}\mathrm{PN} 10+\mathrm{PN} 12 \\
\text { (i.p. + FM both days) }\end{array}$ & 11 & 9 & \multirow{4}{*}{$\begin{array}{l}\text { PN25: Open field } \\
\text { PN28-38: Social } \\
\text { play }\end{array}$} \\
\hline & LPS + saline & $\begin{array}{l}\text { PN10 + PN12 } \\
\text { (i.p. + FM both days) }\end{array}$ & 12 & 9 & \\
\hline & $\begin{array}{l}\text { LPS + } \\
\text { formestane }\end{array}$ & $\begin{array}{l}\text { PN10 + PN12 } \\
\text { (i.p. + FM both days) }\end{array}$ & 9 & 12 & \\
\hline & $\begin{array}{l}\text { Saline + } \\
\text { formestane }\end{array}$ & $\begin{array}{l}\text { PN10 + PN12 } \\
\text { (i.p. + FM both days) }\end{array}$ & 13 & 10 & \\
\hline
\end{tabular}

\begin{tabular}{|c|c|c|c|c|c|c|c|}
\hline \multicolumn{8}{|c|}{ B) Experiments 1B and 1C } \\
\hline & \multirow{2}{*}{$\begin{array}{l}\text { Treatment } \\
\text { group }\end{array}$} & \multirow{2}{*}{$\begin{array}{c}\text { Age at } \\
\text { injections }\end{array}$} & \multicolumn{2}{|c|}{$\begin{array}{c}\text { 1B } \\
\text { E2 levels }\end{array}$} & \multicolumn{2}{|c|}{$\begin{array}{c}\text { 1C } \\
\text { Morphology }\end{array}$} & \multirow{2}{*}{$\begin{array}{l}\text { Age at } \\
\text { tissue } \\
\text { collection }\end{array}$} \\
\hline & & & $\begin{array}{l}M \\
(n)\end{array}$ & $\begin{array}{l}F \\
(n)\end{array}$ & $\begin{array}{c}M \\
(n) \\
\end{array}$ & $\begin{array}{l}F \\
(n)\end{array}$ & \\
\hline \multirow{3}{*}{$\begin{array}{l}\text { Week 1 } \\
\text { (PN1-7) }\end{array}$} & $\begin{array}{l}\text { Vehicle } \\
\text { (saline) }\end{array}$ & $\mathrm{PN} 2+\mathrm{PN} 4$ & 5 & 5 & 4 & 4 & \multirow{3}{*}{ PN6 } \\
\hline & PGE2 & $\mathrm{PN} 2+\mathrm{PN} 4$ & 5 & 6 & 5 & 5 & \\
\hline & LPS & $\mathrm{PN} 2+\mathrm{PN} 4$ & -- & -- & -- & -- & \\
\hline \multirow{3}{*}{$\begin{array}{l}\text { Week } 2 \\
\text { (PN8- } \\
14)\end{array}$} & $\begin{array}{l}\text { Vehicle } \\
\text { (saline) }\end{array}$ & $\mathrm{PN} 10+\mathrm{PN} 12$ & 4 & 4 & 10 & 8 & \multirow{3}{*}{ PN14 } \\
\hline & PGE2 & PN10 + PN12 & 5 & 5 & 5 & 3 & \\
\hline & LPS & PN10 + PN12 & -- & -- & 7 & 5 & \\
\hline \multirow{3}{*}{$\begin{array}{l}\text { Week } 3 \\
\text { (PN15- } \\
21 \text { ) }\end{array}$} & $\begin{array}{l}\text { Vehicle } \\
\text { (saline) }\end{array}$ & PN17 + PN19 & 6 & 6 & 9 & 9 & \multirow{3}{*}{ PN21 } \\
\hline & PGE2 & PN17 + PN19 & 6 & 6 & 4 & 5 & \\
\hline & LPS & PN17 + PN19 & -- & - & 6 & 6 & \\
\hline
\end{tabular}

\begin{tabular}{|l|l|l|c|c|c|}
\hline \multicolumn{1}{|c|}{ D) Experiment 2B } & $\begin{array}{c}\text { Treatment } \\
\text { group }\end{array}$ & $\begin{array}{c}\text { Age at } \\
\text { injections }\end{array}$ & $\begin{array}{c}\text { M } \\
(\boldsymbol{n})\end{array}$ & $\begin{array}{c}\text { F } \\
(\boldsymbol{n})\end{array}$ & $\begin{array}{c}\text { Age at behavior } \\
\text { analysis } \\
\text { (same for all } \\
\text { treatments) }\end{array}$ \\
\hline \multirow{2}{*}{$\begin{array}{c}\text { Week 2 } \\
\text { (PN8-14) }\end{array}$} & $\begin{array}{l}\text { Vehicle } \\
\text { (saline) }\end{array}$ & PN10 + PN12 & 6 & 7 & $\begin{array}{l}\text { PN13: Negative } \\
\text { geotaxis }\end{array}$ \\
\cline { 2 - 5 } $\begin{array}{c}\text { Week 3 } \\
\text { (PN15-21) }\end{array}$ & $\begin{array}{l}\text { Vehicle } \\
\text { (saline) }\end{array}$ & PN17 + PN19 & 11 & 11 & $\begin{array}{l}\text { PN25: Open field } \\
\text { PN28-28: Social } \\
\text { play }\end{array}$ \\
\cline { 2 - 5 } & LPS & PN17 + PN19 & 11 & 11 & PN60: Open field \\
\hline
\end{tabular}

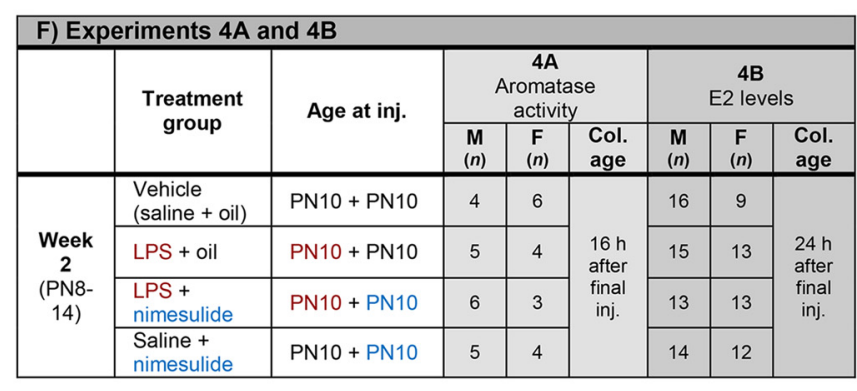

\begin{tabular}{|c|c|c|c|c|c|}
\hline \multicolumn{6}{|c|}{ H) Experiment 4D } \\
\hline & $\begin{array}{c}\text { Treatment } \\
\text { group }\end{array}$ & Age at injections & $\begin{array}{l}M \\
(n)\end{array}$ & $\begin{array}{l}\mathrm{F} \\
(n)\end{array}$ & $\begin{array}{c}\text { Age at } \\
\text { tissue } \\
\text { collection }\end{array}$ \\
\hline \multirow{4}{*}{$\begin{array}{l}\text { Week 2 } \\
\text { (PN8-14) }\end{array}$} & $\begin{array}{l}\text { Vehicle } \\
\text { (saline + oil) }\end{array}$ & $\mathrm{PN} 10,12+\mathrm{PN} 10-14$ & 13 & 12 & \multirow{4}{*}{ PN14 } \\
\hline & LPS + oil & $\mathrm{PN} 10,12+\mathrm{PN} 10-14$ & 12 & 11 & \\
\hline & $\begin{array}{l}\text { LPS + } \\
\text { formestane }\end{array}$ & PN10,12 + PN10-14 & 5 & 5 & \\
\hline & $\begin{array}{l}\text { Saline + } \\
\text { formestane }\end{array}$ & $\mathrm{PN} 10,12+\mathrm{PN} 10-14$ & 6 & 6 & \\
\hline
\end{tabular}

\begin{tabular}{|c|c|c|c|c|c|}
\hline \multicolumn{6}{|c|}{ J) Experiment 4F } \\
\hline & $\begin{array}{l}\text { Treatment } \\
\text { group }\end{array}$ & $\begin{array}{c}\text { Age at } \\
\text { injections }\end{array}$ & $\underset{(n)}{M}$ & $\begin{array}{c}\mathbf{F} \\
(n)\end{array}$ & $\begin{array}{c}\text { Age at behavior } \\
\text { analysis } \\
\text { (same for all } \\
\text { treatments) }\end{array}$ \\
\hline \multirow{4}{*}{$\begin{array}{l}\text { Week } 2 \\
\text { (PN8- } \\
14)\end{array}$} & $\begin{array}{l}\text { Vehicle } \\
\text { (saline + oil) }\end{array}$ & $\begin{array}{l}\mathrm{PN} 10+\mathrm{PN} 12 \\
\text { (i.p. + s.c. both days) }\end{array}$ & 8 & 10 & \multirow{4}{*}{$\begin{array}{l}\text { PN25: Open field } \\
\text { PN28-38: Social } \\
\text { play }\end{array}$} \\
\hline & LPS + oil & $\begin{array}{l}\text { PN10 + PN12 } \\
\text { (i.p. + s.c. both days) }\end{array}$ & 6 & 6 & \\
\hline & $\begin{array}{l}\text { LPS + } \\
\text { nimesulide }\end{array}$ & $\begin{array}{l}\text { PN10 + PN12 } \\
\text { (i.p. + s.c. both days) }\end{array}$ & 7 & 9 & \\
\hline & $\begin{array}{l}\text { Saline + } \\
\text { nimesulide }\end{array}$ & $\begin{array}{l}\mathrm{PN} 10+\text { PN12 } \\
\text { (i.p. + s.c. both days) }\end{array}$ & 9 & 10 & \\
\hline
\end{tabular}

Figure 1. Treatment conditions, post-natal age of animals at treatment, numbers in experiment, and experimental measurements.

tissue was taken at PN14. Numbers per group and age of pups at injection are presented below (Fig. $1 H$ ).

Experiment 4E: Effect of peripheral LPS and intracerebellar formestane on motor and juvenile social play behaviors. Male and female pups were injected peripherally with LPS or vehicle and formestane or vehicle and then assessed for various behaviors. Numbers per group, age of pups at injection and timing of behavioral tests are presented below (Fig. 1I).

Experiment 4F: Effect of peripheral LPS and intracerebellar nimesulide on motor and juvenile social play behaviors. Male and female pups were injected peripherally with LPS or vehicle and nimesulide or vehicle and 
then assessed for various behaviors. Numbers per group, age of pups at injection, and timing of behavioral tests are presented below (Fig. $1 J$ ).

\section{Statistics}

Statistical comparisons were made by two- or three-way ANOVA omnibus analysis for sex, treatment, and sometimes age followed by Tukey's post hoc analysis. For clarity, only significant interactions and main effects are reported in the text. All post hoc significant comparisons are noted in the figures and irrelevant nonsignificant comparisons are not reported. For the social play behavior, data were recorded on several sessions spaced 2-4 $\mathrm{d}$ apart, so we used a repeated-measures ANOVA with treatment and sex as the factors. For the qPCR data, two-way MANOVAs were performed to help control for intrasample variability with Tukey's HSD post hoc comparison.

\section{Results}

Experiment 1A: Exposure to LPS increased cerebellar PGE2 content during the second and not first or third postnatal weeks

Male and female rat pups were challenged immunologically with LPS in the middle of the first, second, or third week of life. Regardless of whether LPS was given once (on PN10) or twice (on PN9 and PN10), week 2 animals had elevated PGE2 in the posterior vermis $6 \mathrm{~h}$ after the last treatment compared with controls $\left(F_{\text {treatment }}=5.74, p=0.005\right.$; Fig. 2A). The additional day of LPS treatment did not elevate PGE2 levels further. No significant interactions or effects of sex were detected. Hereafter and unless otherwise stated (see "Social play behavior" section), there were no effects of sex or interactions between sex and age or sex and treatment.

In contrast to week 2, treatment with LPS during week 1 did not increase PGE2 content $\left(F_{\text {treatment }}=0.202, p=0.66\right)$. Likewise, there was no effect of LPS treatment during week 3 on PGE2 content regardless of the number of times LPS was given $\left(F_{\text {treatment }}=0.103, p=0.9\right)$. To confirm the efficacy of the LPS treatment, PGE2 was measured in the POA of a subset of the same animals and found to significantly increase $\left(F_{\text {treatment }}=5.58, p=\right.$ 0.026 ; Fig. $2 A$, confirming the ability of the animal to respond to LPS at this age.

\section{Experiment 1B: Exposure to PGE2 increased cerebellar E2} content during the second but not first or third postnatal weeks PGE2 was infused directly into the cerebellum on $2 \mathrm{~d}$ during the first, second, or third postnatal week. E2 content in the posterior vermis increased after PGE2 during the second week, but was

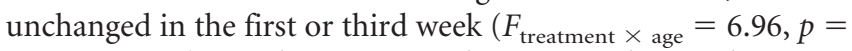
0.002; Fig. $2 B$ ). Basal E2 content also increased at week 2 compared with week 3 (Tukey's HSD, $p=0.02$ ).

\section{Experiment 1C: Exposure to LPS or PGE2 decreased the length of Purkinje cell dendritic trees during the second but not first or third postnatal weeks}

Purkinje cell dendritic length was measured at the end of the first, second, or third week. Treatment with either LPS or PGE2 significantly decreased Purkinje cell dendritic length, but only during the second postnatal week. PGE2 versus LPS treatment effects did not differ from each other $\left(F_{\text {treatment } \times \text { age }}=6.84, p<0.001\right.$; Fig. $\left.2 C\right)$.

\section{Experiment 2A: Increased intracerebellar PGE2 during the second but not the third week reduced later social play behavior but only in males}

Juvenile male rats engage in social play more frequently than females (Meaney and Stewart, 1981). This sex difference was evident here, but only males decreased their play if they experienced treatment with PGE2 during the second postnatal week (week 2:
$F_{\text {treatment } \times \text { sex }}=10.34, p=0.004$; Fig. $3 A$ ). There were no effects of any treatment on either sex on negative geotaxis, duration of wire hang, or activity in an open field in the same animals.

\section{Experiment 2B: LPS exposure during the second but not the} third week reduced later social play behavior but only in males

Similarly, juvenile male rats played less if they were exposed to

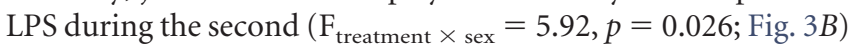
but not third postnatal week. There were no effects of any treatment on either sex on negative geotaxis, duration of wire hang, or activity in an open field in the same animals.

\section{Experiment 3A: LPS treatment increased mRNA for COX-2,} mPGE synthase-1, and Mgll, but only Mgll is specifically induced during the second week

We next sought to determine whether the genes for PGE2 production change in their response to LPS across the first 3 weeks. MAG-lipase (Mgll) mRNA peaked during the second week and LPS treatment increased mRNA still further, but only during the second and not the first or third weeks of life $\left(F_{\text {age }} \times\right.$ treatment $=$ $3.72, p=0.034)$. Conversely, COX-2 (Ptgs2) mRNA, along with mPGES-1 (Pges1) mRNA, increased in response to LPS regardless of age $\left(\right.$ COX $-2: F_{\text {age }} \times$ treatment $=5.19, p=0.01 ;$ mPGES- 1 : $\left.F_{\text {treatment }}=17.98, p<0.001\right)$. There were no effects of treatment, age, or sex on COX-1 (Ptgs1) mRNA expression (Fig. 4A).

\section{Experiment 3B: Dynamic changes in mRNA levels of the} PGE2-E2 pathway component define the critical period There were three notable patterns in the mRNA expression profiles of the components of the PGE2-E2 pathway across the first 3 weeks of life (Fig. 4B). The first was that several components started low and either stayed low (COX-1, mPGE synthase-1, ER- $\beta$ ) or dropped still further across the 3 weeks (EP2 and EP3). The second was that some components began to rise during the second week and either plateaued (MAGL) or continued to rise into the third week (COX-2 and EP4). The third was that those components that rose dramatically during the second week then dropped precipitously during the third week to levels below those seen at birth (ER- $\alpha$ and aromatase). Significant differences were assessed by two-way ANOVA with sex and day as factors. There were no significant effects of sex. Differences between days were assessed by Tukey's HSD following a main effect of age. Points of the same color with different letters are statistically significant. No comparisons were made between the quantified mRNAs.

Experiments 4A and 4B: Peripheral LPS exposure increases cerebellar aromatase activity and estradiol content and this is prevented by inhibition of COX-2

Peripheral administration of LPS increased aromatase activity in the cerebellum $16 \mathrm{~h}$ later, and coadministration of the COX-2 inhibitor nimesulide prevented this increase $\left(F_{\text {treatment }}=10.94\right.$, $p<0.001$; Fig. 5A). LPS treatment also increased cerebellar estradiol content $24 \mathrm{~h}$ later and this was prevented by coadministering nimesulide $\left(F_{\text {treatment }}=5.85, p=0.001\right.$; Fig. $\left.5 B\right)$.

Experiment 4C: PGE2-induced aromatase activity is blocked by the PKA signaling disrupter $\mathrm{Ht} 31$

EP2 and EP4 receptors for PGE2 are adenylate cyclase linked and highly expressed in the cerebellum during the second postnatal week. PGE2 effects on brain development can be mediated via PKA activation after EP2 and EP4 receptor activation (Wright and McCarthy, 2009). Intracerebellar injections of PGE2 elevated 

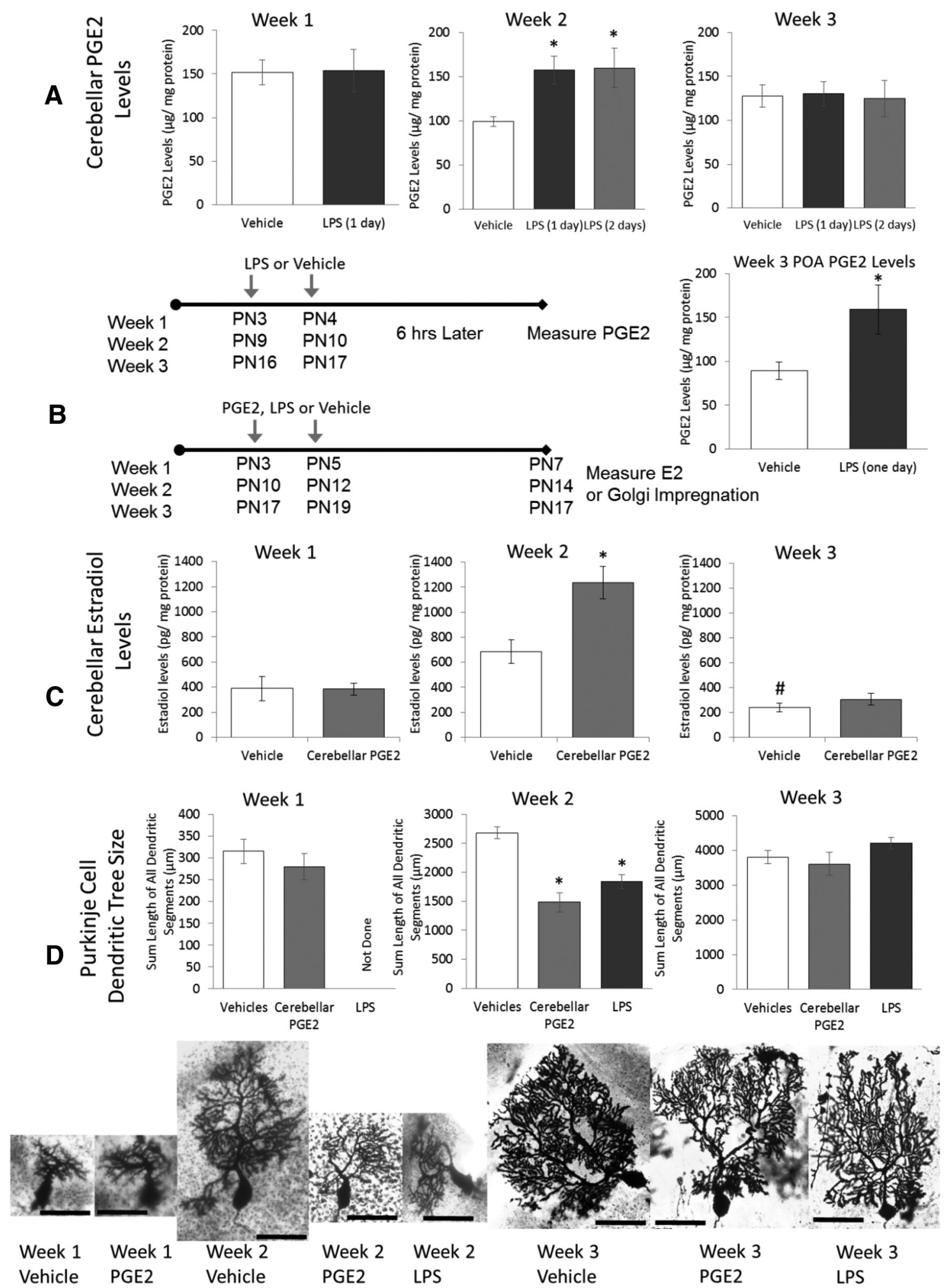

Figure 2. The second week of life is a sensitive period in Purkinje cell development. $A$, Neonatal rats received LPS intraperitoneally in the middle of the first, second, or third postnatal week and cerebellar PGE2 was assayed $6 \mathrm{~h}$ later. Peripheral LPS increased cerebellar PGE2 only during the second week $(p=0.01)$ and 2 injections of LPS on consecutive days also increased cerebellar PGE2 $(p=0.002)$, but without additional effect $(p=0.99)$. Treatment with LPS during the third week increased PGE2 levels in the P0A $\left({ }^{*} p<0.026\right)$, demonstrating the capacity of the brain to respond to inflammation. $\boldsymbol{B}$, Neonatal rats received PGE2 infusion directly into the cerebellum during the first, second, or third postnatal week and were humanely killed at the end of the respective week. PGE2 treatment increased estradiol levels, but only during the second week of life ( ${ }^{*} p=0.002$ vs vehicle). Basal levels of estradiol were higher during the second week compared with the third $(\# p=0.02)$. C, Either intracerebellar infusion of PGE2 or peripheral injection of LPS reduced Purkinje dendrite length, but only during the second week ( ${ }^{*} p<0.01$ vs vehicle). $\boldsymbol{D}$, Images of Golgi-Cox impregnated Purkinje neurons representative of each group. Scale bar, $50 \mu \mathrm{m}$. Two- or three-way ANOVAs, $p<0.05$, and Tukey's HSD $p$-value are reported. 


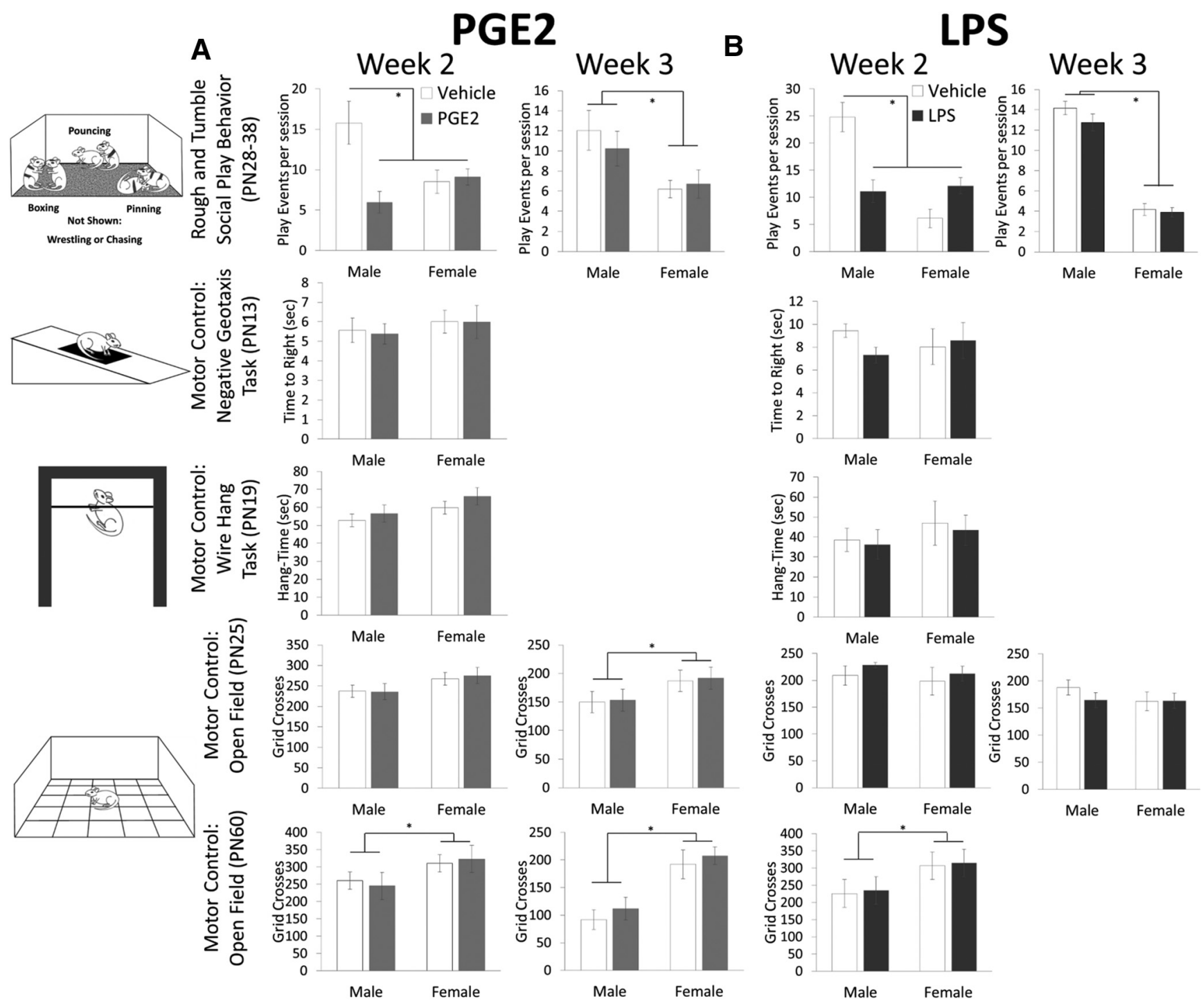

Figure 3. Treatment with PGE2 or LPS during the second postnatal week impairs juvenile social play behavior but not motor control in males. $\boldsymbol{A}$, Treatment with PGE2 during the second postnatal week reduced the number of play events seen in juvenile males $\left({ }^{*} p=0.002 ;\right.$ PN28-38) to the already low level seen in females. PGE2 treatment during the third week had no effect on either sex, although males still played more than females ( ${ }^{*} p<0.001$ ). There was no effect of treatment with PGE2 during either week on motor control assessed with the negative geotaxis, wire hang, and open-field test, with the latter being done at both juvenile and adult ages, although females locomoted more than males $\left({ }^{*} p<0.05\right)$. $\boldsymbol{B}$, An identical pattern of behavioral responses was evident in animals treated with LPS. ${ }^{*} p<0.005$ all, 3-way ANOVAs, $p<0.05$, Tukey's HSD.

aromatase activity and coadministration of $\mathrm{Ht} 31$, a disruptor of type-2 PKA signaling, prevented this elevation $\left(F_{\text {treatment }}=7.54\right.$, $p=0.001$; Fig. 5C).

Experiment 4D: Peripheral LPS exposure stunts the dendritic growth of Purkinje cells and this is prevented by coadministration of an aromatase inhibitor into the cerebellum

Coadministration of formestane into the cerebellum with peripheral LPS on PN10 and PN12 prevented the reduction in total length of all dendritic segments of Purkinje cells observed with LPS treatment alone $\left(F_{\text {treatment }}=22.21, p<0.001\right.$; Fig. $\left.5 D\right)$.

Experiment 4E: Peripheral LPS exposure impairs social play behavior in males and coadministration of an aromatase inhibitor into the cerebellum prevents it

Administration of LPS reduced social play behavior in males and coadministration of formestane into the cerebellum completely prevented this reduction $\left(F_{\mathrm{sex}} \times\right.$ treatment $=7.77, p=0.0001$; Fig. $5 E$ ). There were no effects of treatment on play behavior by females. There were no effects of treatment on open field of these animals (data not shown). There were no effects of treatment with LPS, 1 week of daily subcutaneous formestane, or LPS coadministration of subcutaneous formestane on wire hang, negative geotaxis, or open-field behavior of another cohort of animals (see Fig. 2 for data from LPS-treated animals).

Experiment 4F: Peripheral LPS exposure impairs social play behavior in males and coadministration of the COX-2 inhibitor nimesulide prevents it

Similarly, the coadministration of subcutaneous nimesulide at the same time as LPS (PN10 and PN12) completely prevented the reductions in social play behavior seen in males $\left(F_{\text {sex }} \times\right.$ treatment $=$ $6.05, p=0.0001$; Fig. $5 F$ ). There were no effects of treatment on open-field behavior of these animals (data not shown). 

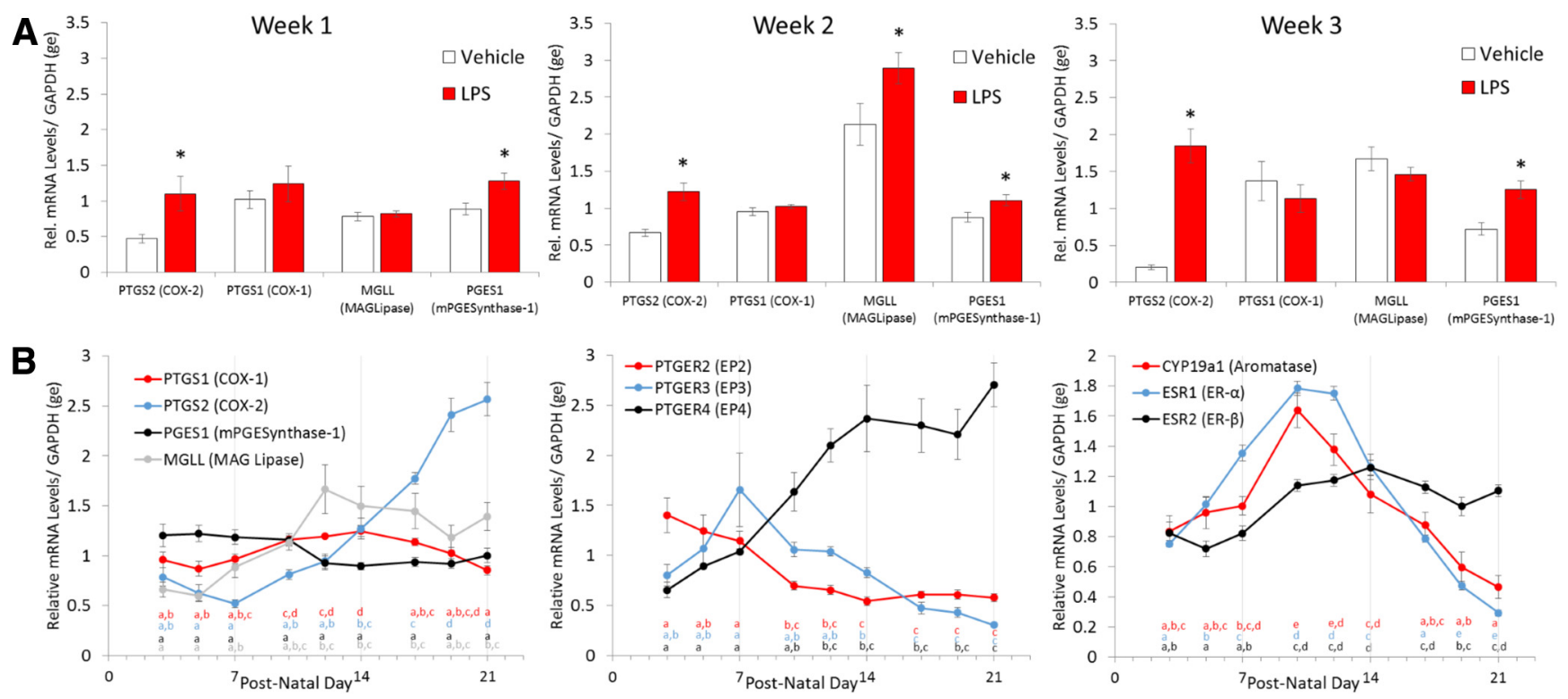

Figure 4. Dynamic changes in mRNA levels of the PGE2-E2 pathway components define the sensitive period. $A$, Peripheral LPS treatment increased mRNA for the inducible form of COX (Ptgs2) and microsomal PGES1 during each of the first 3 postnatal weeks $\left({ }^{*} p<0.05\right)$. In the brain, Mgll is essential for the production of AA, the substrate for the COX enzymes, and increased after LPS treatment only during the second week ( ${ }^{*} p<0.03$ v s all others). $\boldsymbol{B}$, Developmental profile of mRNA levels for the enzymes and receptors that constitute the PGE2-E2 pathway is divided into those associated with PGE2 synthesis (left), receptors for PGE2 (middle), and those associated with estradiol action (right). MANOVAs, Tukey's HSD p-value are reported, letters of the same color represent statistically homogeneous groups. Time points of the same color not sharing a letter statistically differ by $p<0.05$.

\section{Discussion}

We have identified a novel role for PGE2 in cerebellar development in activating the estradiol-synthesizing enzyme aromatase to regulate normal Purkinje neuron development (Dean et al., 2012a; Dean et al., 2012b). In this regard, PGE2 is acting as an endogenous signaling molecule. It remained to be determined whether this cerebellar pathway was also sensitive to inflammation. Here, we show that PGE2 signaling is subject to dysregulation by inflammation and that this influence occurs selectively during the second, but not first or third, postnatal week in the rat. Moreover, we have discovered a tightly orchestrated intrinsic gene expression profile that confers enhanced sensitivity to peripheral inflammation with enduring consequences for Purkinje neuron development and social behaviors.

During the second week of life, exposure to LPS increased cerebellar PGE2 content in the posterior vermis within $6 \mathrm{~h}$, aromatase activity within $16 \mathrm{~h}$, and estradiol content within $24 \mathrm{~h}$. Coadministration of the COX-2 inhibitor nimesulide prevented these increases. Direct PGE2 administration into the cerebellum also increased aromatase activity within $16 \mathrm{~h}$ and the increase in estradiol content in the cerebellum was maintained for at least 2 d. Exposure to PGE2 or LPS at the middle of the second week triggered a reduction in the length of Purkinje cell dendrites by the end of the week and impaired the expression of social play behavior in juvenile males. The reduction in dendritic length was prevented by coadministering the aromatase inhibitor formestane with LPS (see Fig. $5 G$ for summary of mechanism). Moreover, the behavioral effects of peripheral LPS are localized to the cerebellum as injection of formestane into the cerebellum prevented the impairments in male social play behavior. The social deficits observed were in contrast to the lack of any evidence of overt motor or sensory deficits induced by PGE2 or LPS treatment. Therefore, during the second week of life, PGE2 can act as a sentinel integrator of exogenous inflammatory cues into an endogenous signaling pathway to affect social behavior through a circuit that depends upon normal cerebellar development.
In contrast, exposure to LPS or PGE during weeks 1 and 3 had no effect on measures of biochemistry, morphology, or behavior. There was no increase in cerebellar PGE2 after LPS, but levels did increase in the POA of the same animals during week 3, confirming the ability of the animal to respond to a mimetic of infection. In addition, PGE2 injection into the cerebellum during either week 1 or 3 did not increase estradiol content and neither LPS nor PGE2 treatment at the same times affected the dendritic tree of Purkinje cells or later male social play behavior. These data indicate that the second postnatal week is a sensitive period for inflammation-induced changes to the cerebellar PGE2-E2 pathway, but do not suggest why it is a critical period.

To identify parameters of the critical period, we analyzed the gene expression of key enzymes and receptors across the first 3 weeks of life and in response to inflammation. In the brain, Mgll is the principal producer of the AA substrate shuttled to the COX enzymes that synthesize prostaglandins. The availability of AA is the primary limitation to PGE2 synthesis (Nomura et al., 2011). Interestingly, Mgll mRNA peaked during the second postnatal week and LPS treatment increased mRNA still further, but only during the second week. In contrast, COX-2 (Ptgs2) mRNA also increased during the second week as part of normal development, but LPS treatment further increased COX-2 along with PGES-1 regardless of age. However, increased COX-2 can only synthesize more PGE2 if sufficient substrate is available. During the second week, the elevated levels of Mgll should provide ample AA, but the failure of inflammation to induce mRNA during the third week stops the production of AA and thus PGE2. Therefore, Mgll supersedes COX-2 in determining the sensitive period. Perhaps more importantly, both the synthesis and transduction of estradiol are markedly regulated. The levels of mRNA for ER- $\alpha$ (Esr1) and aromatase (Cyp19A1) peaked during the second week and then plummeted during the third week to levels below those seen just after birth. Therefore, there is little estradiol produced during the third week and that which is synthesized has little receptor to bind to (although there is Esr2 present). Therefore, an intrinsic 


\section{A}
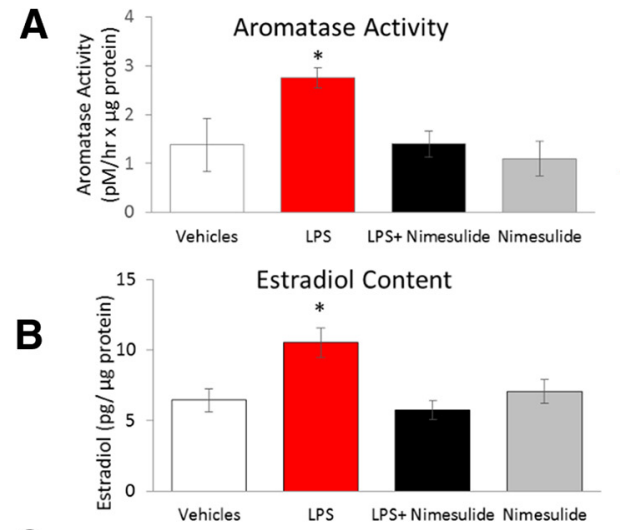

C
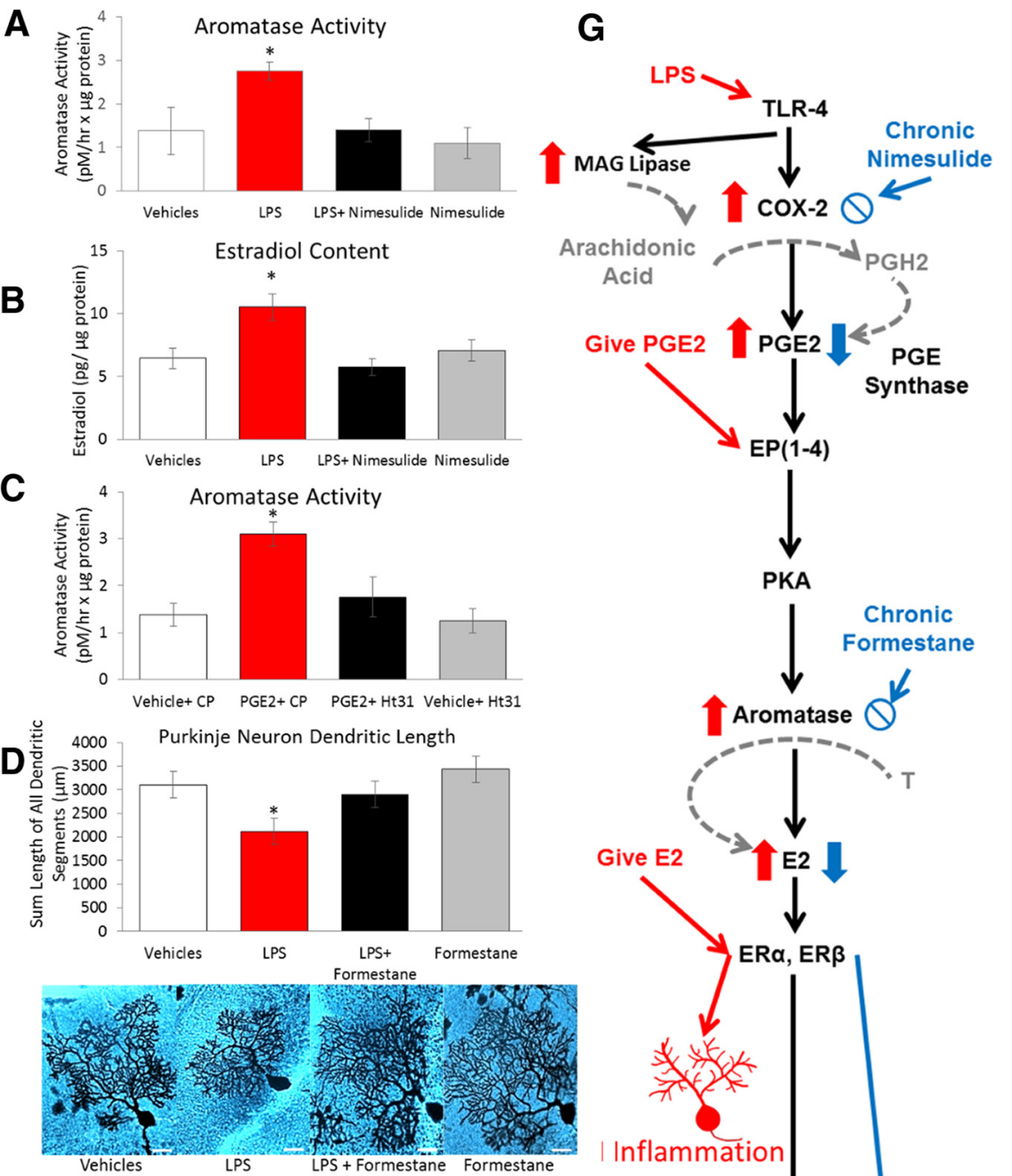

E
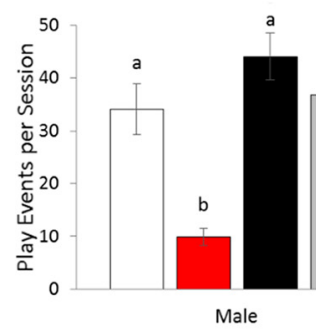

$\square$ Vehicles

\section{(1)}

$\mathbf{F}$

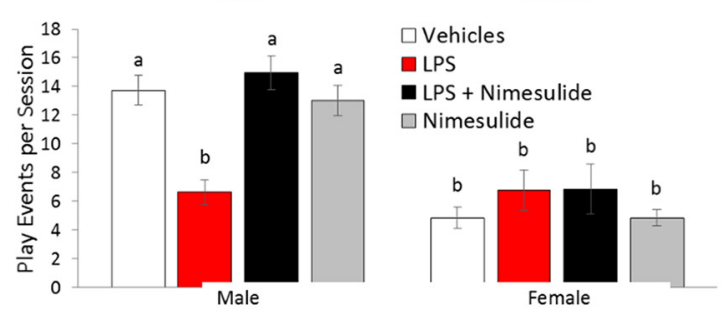

developmental program of gene expression protects the cerebellum from inflammation during the first and third weeks, but creates a sensitive period during the second week, a time critical to Purkinje cell maturation.

Estradiol is traditionally considered a female sex hormone derived from the gonads, although in rodents, it is also the principal steroid driving masculinization of the brain (McCarthy, 2008). One of the more striking findings in our dataset was the complete absence of sex differences in any of the parameters defining the critical period and sensitivity to inflammation. There were no differences between males and females in gene expression for the 10 genes examined at nine developmental time points or in Purkinje neuron morphology or synthesis of PGE2 or E2. Despite this, only males were negatively affected on social play behavior. Females naturally play at a lower rate than males, but the rate can go lower still (Argue and McCarthy, 2015), suggesting that the lack of effect in females is not due to a basement effect.

Estradiol has been implicated previously in cerebellar development and adult functioning (Abel et al., 2011; Hedges et al., 2012). Estradiol induction of BDNF promotes growth of the Purkinje neuron dendritic tree (Sakamoto et al., 2003; Haraguchi et al., 2012), consistent with the notion of a trophic action of this locally synthesized neurosteroid. The $\beta$ isoform of the ER is found in differentiating cells early in cerebellar development (Jakab et al., 2001) and activation of this same receptor enhances motor memory in adults (Andreescu et al., 2007). Early studies suggested ER- $\alpha$ was not present in adult cerebellum (Smith et al., 1987; Smith et al., 1989) and our results corroborate this by demonstrating a dramatic downregulation by the end of the third postnatal week.

Early in life, the cerebellum helps to refine and shape the development of neocortical circuits for affect and cognition by processing sensory and internal information within its closed-loop circuitry with multiple cortical regions (Andreasen and Pierson, 2008). This contrasts with its role later in life as intrinsic to motor learning (Allin et al., 2001; Tavano et al., 2007). The cerebellar hemispheres and vermis have both distinct and overlapping roles (Hibi and Shimizu, 2012). Damage to the posterior vermis developmentally corresponds with the affective symptoms of cerebellar cognitive syndrome such as anxiety, blunted or inappropriate social behavior, and per-

Figure 5. Effects of cerebellar inflammation are mediated by local PGE2 and estradiol production. $A, B$, Peripheral treatment with LPS increased aromatase activity and estradiol content in the cerebellum and both effects were prevented by coadministration of the COX-2 inhibitor nimesulide ( ${ }^{*} p<0.04$ vs all other groups). C, Intracerebellar infusion of PGE2 also increased aromatase activity and this effect was blocked by the PKA disruptor Ht31, consistent with a role for EP2 and EP4 receptors in PGE2 action $\left({ }^{*} p<\right.$ 0.03 vs all other groups). D, LPS treatment reduced Purkinje dendrite length, but this was prevented by coadministration of the aromatase inhibitor formestane ( ${ }^{*} p<0.001$ vs all other groups). Images of Golgi-Cox impregnated Purkinje neurons representative of each group are presented. Scale bar, $25 \mu \mathrm{m} . \boldsymbol{E}, \boldsymbol{F}$, Peripheral LPS treatment during the second postnatal week reduced later social play in males and this was prevented by intracerebellar infusion of formestane $(p=0.001 ; \boldsymbol{E})$ or peripheral nimesulide $(p=0.001 ; \boldsymbol{F})$. Letters represent statistically homogeneous groups; conditions not sharing letters differ by $p<0.05$. G, Schematic diagram of the PGE2-E2 pathway, the agents that modify it, and the impact on the Purkinje cell dendritic tree. Two-way ANOVAs, $p<0.05$, and Tukey's HSD $p$-values are reported. 
sonality changes, whereas damage to the posterior hemispheres predicts cognitive impairments such as disturbances in decision making, planning, working memory, visuospatial reasoning, and speech generation (Levisohn et al., 2000; Riva and Giorgi, 2000; Scott et al., 2001). Damage to the cerebellum in infancy is strongly associated with autism spectrum disorder (ASD) (Courchesne et al., 2007; Hampson and Blatt, 2015), and in the 26 mouse models of ASD, the cerebellar cortex is unfailingly abnormal (Ellegood et al., 2015). Knock-out of the tuberous sclerosis gene (TSC1) specifically in Purkinje cells of mice causes impaired social interactions, diminished mother-pup interactions, and perseveration in T-maze assessments (Tsai et al., 2012). Inhibition of mTOR, which is downstream of TSC1, restores behavior to normal if it is specifically timed to PN7, further underscoring the importance of the second week of cerebellar development. Pathologies of the cerebellum are also strongly associated with schizophrenia, but how is less understood than for ASD (Andreasen and Pierson, 2008).

Early life inflammation, particularly during gestation, is a risk factor for neuropsychiatric disorders (Brown et al., 2014). The sensitive period for negative effects from gestational inflammation are the first and second trimester for bacterial versus viral inflammation, respectively (Patterson, 2012). However, these periods are too early for refinement of circuits relevant to social and affective disorders. The notion of a frank association between early childhood inflammation and diagnosis of ASD has been discredited (Halsey et al., 2001; Atladóttir et al., 2010). However, one hallmark of ASD is ongoing immune system abnormalities in the cerebellum well into adolescence, a time when the cerebellum refines social and affective behaviors. These abnormalities include prolonged activation of microglia and elevated cytokines (Gupta et al., 2014; Masi et al., 2015). Therefore, the potential exists for later sensitive periods of maturation and signaling that are specific to the cerebellum and may interface with genetic predisposition and/or earlier inflammatory insults.

In summary, our results implicate prostaglandins as an overlooked component of the inflammatory cascade that can profoundly influence brain development and behavior due to their role as sentinel integrators of exogenous and endogenous cues. This integration may occur during select critical periods, highlighting the complexity of understanding the role of exogenous insult on brain development.

\section{References}

Abel JM, Witt DM, Rissman EF (2011) Sex differences in the cerebellum and frontal cortex: roles of estrogen receptor alpha and sex chromosome genes. Neuroendocrinology 93:230-240. CrossRef Medline

Allin M, Matsumoto H, Santhouse AM, Nosarti C, AlAsady MH, Stewart AL, Rifkin L, Murray RM (2001) Cognitive and motor function and the size of the cerebellum in adolescents born very pre-term. Brain 124:60-66. CrossRef Medline

Altman J (1972) Postnatal development of the cerebellar cortex in the rat. II. Phases in the maturation of Purkinje cells and of the molecular layer. J Comp Neurol 145:399-463. CrossRef Medline

Amateau SK, McCarthy MM (2002) A novel mechanism of dendritic spine plasticity involving estradiol induction of prostglandin-E2. J Neurosci 22:8586-8596. Medline

Amateau SK, McCarthy MM (2004) Induction of PGE(2) by estradiol mediates developmental masculinization of sex behavior. Nat Neurosci 7:643-650. CrossRef Medline

Andreasen NC, Pierson R (2008) The role of the cerebellum in schizophrenia. Biol Psychiatry 64:81-88. CrossRef Medline

Andreescu CE, Milojkovic BA, Haasdijk ED, Kramer P, De Jong FH, Krust A, De Zeeuw CI, De Jeu MT (2007) Estradiol improves cerebellar memory formation by activating estrogen receptor beta. J Neurosci 27:1083210839. CrossRef Medline

Argue KJ, McCarthy MM (2015) Characterization of juvenile play in rats: importance of sex of self and sex of partner. Biol Sex Differ 6:16. CrossRef Medline

Atladóttir HO, Thorsen P, Schendel DE, Østergaard L, Lemcke S, Parner ET (2010) Association of hospitalization for infection in childhood with diagnosis of autism spectrum disorders: a Danish cohort study. Arch Pediatr Adolesc Med 164:470-477. Medline

Attwell D, Buchan AM, Charpak S, Lauritzen M, Macvicar BA, Newman EA (2010) Glial and neuronal control of brain blood flow. Nature 468:232243. CrossRef Medline

Bezzi P, Carmignoto G, Pasti L, Vesce S, Rossi D, Rizzini BL, Pozzan T, Volterra A (1998) Prostaglandins stimulate calcium-dependent glutamate release in astrocytes. Nature 391:281-285. CrossRef Medline

Biegon A, Kim SW, Alexoff DL, Jayne M, Carter P, Hubbard B, King P, Logan J, Muench L, Pareto D, Schlyer D, Shea C, Telang F, Wang GJ, Xu Y, Fowler JS (2010) Unique distribution of aromatase in the human brain: in vivo studies with PET and [N-methyl-11C]vorozole. Synapse 64: 801-807. CrossRef Medline

Blatteis CM, Li S, Li Z, Feleder C, Perlik V (2005) Cytokines, PGE2 and endotoxic fever: a re-assessment. Prostaglandins Other Lipid Mediat 76: 1-18. CrossRef Medline

Brown AS, Sourander A, Hinkka-Yli-Salomäki S, McKeague IW, Sundvall J, Surcel HM (2014) Elevated maternal C-reactive protein and autism in a national birth cohort. Mol Psychiatry 19:259-264. CrossRef Medline

Buckner RL, Krienen FM, Castellanos A, Diaz JC, Yeo BT (2011) The organization of the human cerebellum estimated by intrinsic functional connectivity. J Neurophysiol 106:2322-2345. CrossRef Medline

Chell S, Kaidi A, Williams AC, Paraskeva C (2006) Mediators of PGE2 synthesis and signalling downstream of COX-2 represent potential targets for the prevention/treatment of colorectal cancer. Biochim Biophys Acta 1766:104-119. Medline

Courchesne E, Pierce K, Schumann CM, Redcay E, Buckwalter JA, Kennedy DP, Morgan J (2007) Mapping early brain development in autism. Neuron 56:399-413. CrossRef Medline

Dean SL, Knutson JF, Krebs-Kraft DL, McCarthy MM (2012a) Prostaglandin E2 is an endogenous modulator of cerebellar development and complex behavior during a sensitive postnatal period. Eur J Neurosci 35: 1218-1229. CrossRef Medline

Dean SL, Wright CL, Hoffman JF, Wang M, Alger BE, McCarthy MM (2012b) Prostaglandin E2 stimulates estradiol synthesis in the cerebellum postnatally with associated effects on purkinje neuron dendritic arbor and electrophysiological properties. Endocrinology 153:5415-5427. CrossRef Medline

Ellegood J et al. (2015) Clustering autism: using neuroanatomical differences in 26 mouse models to gain insight into the heterogeneity. Mol Psychiatry 20:118-125. CrossRef Medline

Gupta S, Ellis SE, Ashar FN, Moes A, Bader JS, Zhan J, West AB, Arking DE (2014) Transcriptome analysis reveals dysregulation of innate immune response genes and neuronal activity-dependent genes in autism. Nat Commun 5:5748. CrossRef Medline

Halsey NA, Hyman SL; Conference Writing Panel (2001) Measles-mumpsrubella vaccine and autistic spectrum disorder: report from the New Challenges in Childhood Immunizations Conference convened in Oak Brook, Illinois, June 12-13, 2000. Pediatrics 107:E84. CrossRef Medline

Hampson DR, Blatt GJ (2015) Autism spectrum disorders and neuropathology of the cerebellum. Front Neurosci 9:420. CrossRef Medline

Haraguchi S, Sasahara K, Shikimi H, Honda S, Harada N, Tsutsui K (2012) Estradiol promotes purkinje dendritic growth, spinogenesis, and synaptogenesis during neonatal life by inducing the expression of BDNF. Cerebellum 11:416-417. CrossRef Medline

Hedges VL, Ebner TJ, Meisel RL, Mermelstein PG (2012) The cerebellum as a target for estrogen action. Front Neuroendocrinol 33:403-411. CrossRef Medline

Hibi M, Shimizu T (2012) Development of the cerebellum and cerebellar neural circuits. Dev Neurobiol 72:282-301. CrossRef Medline

Jakab RL, Wong JK, Belcher SM (2001) Estrogen receptor $\beta$ immunoreactivity in differentiating cells of the developing rat cerebellum. J Comp Neurol 430:396-409. CrossRef Medline

Kakizawa S, Yamasaki M, Watanabe M, Kano M (2000) Critical period for activity-dependent synapse elimination in developing cerebellum. J Neurosci 20:4954-4961. Medline

Konkle AT, McCarthy MM (2011) Developmental time course of estradiol, 
testosterone, and dihydrotestosterone levels in discrete regions of male and female rat brain. Endocrinology 152:223-235. CrossRef Medline

Levisohn L, Cronin-Golomb A, Schmahmann JD (2000) Neuropsychological consequences of cerebellar tumour resection in children: cerebellar cognitive affective syndrome in a paediatric population. Brain 123: 1041-1050. CrossRef Medline

Masi A, Quintana DS, Glozier N, Lloyd AR, Hickie IB, Guastella AJ (2015) Cytokine aberrations in autism spectrum disorder: a systematic review and meta-analysis. Mol Psychiatry 20:440-446. CrossRef Medline

McCarthy MM (2008) Estradiol and the developing brain. Physiological reviews 88:91-124. CrossRef Medline

Meaney MJ, Stewart J (1981) Neonatal androgens influence the social play of prepubescent rats. Horm Behav 15:197-213. CrossRef Medline

Naftolin F (1994) Brain aromatization of androgens. J Reprod Med 39: 257-261. Medline

Nomura DK, Morrison BE, Blankman JL, Long JZ, Kinsey SG, Marcondes MC, Ward AM, Hahn YK, Lichtman AH, Conti B, Cravatt BF (2011) Endocannabinoid hydrolysis generates brain prostaglandins that promote neuroinflammation. Science 334:809-813. CrossRef Medline

Patterson PH (2012) Maternal infection and autism. Brain Behav Immun 26:393. CrossRef Medline

Rage F, Lee BJ, Ma YJ, Ojeda SR (1997) Estradiol enhances prostaglandin E2 receptor gene expression in luteinizing hormone-releasing hormone (LHRH) neurons and facilitates the LHRH response to PGE2 by activating a glia-to-neuron signaling pathway. J Neurosci 17:9145-9156. Medline

Riva D, Giorgi C (2000) The cerebellum contributes to higher functions during development: evidence from a series of children surgically treated for posterior fossa tumours. Brain 123:1051-1061. CrossRef Medline

Roth A, Häusser M (2001) Compartmental models of rat cerebellar Purkinje cells based on simultaneous somatic and dendritic patch-clamp recordings. J Physiol 535:445-472. CrossRef Medline

Sakamoto H, Mezaki Y, Shikimi H, Ukena K, Tsutsui K (2003) Dendritic growth and spine formation in response to estrogen in the developing Purkinje cell. Endocrinology 144:4466-4477. CrossRef Medline

Sasano H, Takahashi K, Satoh F, Nagura H, Harada N (1998) Aromatase in the human central nervous system. Clin Endocrinol (Oxf) 48:325-329. CrossRef Medline

Savonenko A, Munoz P, Melnikova T, Wang Q, Liang X, Breyer RM, Montine
TJ, Kirkwood A, Andreasson K (2009) Impaired cognition, sensorimotor gating, and hippocampal long-term depression in mice lacking the prostaglandin E2 EP2 receptor. Exp Neurol 217:63-73. CrossRef Medline

Schmahmann JD, Sherman JC (1998) The cerebellar cognitive affective syndrome. Brain 121:561-579. CrossRef Medline

Scott RB, Stoodley CJ, Anslow P, Paul C, Stein JF, Sugden EM, Mitchell CD (2001) Lateralized cognitive deficits in children following cerebellar lesions. Dev Med Child Neurol 43:685-691. CrossRef Medline

Smith SS, Waterhouse BD, Woodward DJ (1987) Sex steroid effects on extrahypothalamic CNS.II. Progesterone, alone and in combination with estrogen, modulates cerebellar responsiveness to amino acid neurotransmitters. Brain Res 422:52-62. CrossRef Medline

Smith SS, Woodward DJ, Chapin JK (1989) Sex steroids modulate motorcorrelated increases in cerebellar discharge. Brain Res 476:307-316. CrossRef Medline

Stoodley CJ, Schmahmann JD (2010) Evidence for topographic organization in the cerebellum of motor control versus cognitive and affective processing. Cortex 46:831-844. CrossRef Medline

Strick PL, Dum RP, Fiez JA (2009) Cerebellum and nonmotor function. Annu Rev Neurosci 32:413-434. CrossRef Medline

Tanaka K, Furuyashiki T, Kitaoka S, Senzai Y, Imoto Y, Segi-Nishida E, Deguchi Y, Breyer RM, Breyer MD, Narumiya S (2012) Prostaglandin E2mediated attenuation of mesocortical dopaminergic pathway is critical for susceptibility to repeated social defeat stress in mice. J Neurosci 32: 4319-4329. CrossRef Medline

Tavano A, Grasso R, Gagliardi C, Triulzi F, Bresolin N, Fabbro F, Borgatti R (2007) Disorders of cognitive and affective development in cerebellar malformations. Brain 130:2646-2660. CrossRef Medline

Tsai PT, Hull C, Chu Y, Greene-Colozzi E, Sadowski AR, Leech JM, Steinberg J, Crawley JN, Regehr WG, Sahin M (2012) Autistic-like behaviour and cerebellar dysfunction in Purkinje cell Tsc1 mutant mice. Nature 488: 647-651. CrossRef Medline

Wang VY, Zoghbi HY (2001) Genetic regulation of cerebellar development. Nat Rev Neurosci 2:484-491. CrossRef Medline

Wright CL, McCarthy MM (2009) Prostaglandin E2-induced masculinization of brain and behavior requires protein kinase A, AMPA/kainate, and metabotropic glutamate receptor signaling. J Neurosci 29:13274-13282. CrossRef Medline 